\title{
Platyspondylic dysplasia, Torrance type
}

INSERM

\section{Source}

INSERM. (1999). Orphanet: an online rare disease and orphan drug data base.

Platyspondylic dysplasia, Torrance type. ORPHA:85166

Platyspondylic lethal skeletal dysplasia (PLSD), Torrance type (PLSD-T) is a skeletal dysplasia characterised by severe limb shortening (short and broad long bones), platyspondyly with wafer-like vertebral bodies, short ribs with anterior cupping, severe hypoplasia of the lower ilia and radial bowing. Histological findings include slightly enlarged chondrocytes and hypercellularity. The prevalence is unknown. The disorder is transmitted as an autosomal dominant trait and is caused by mutations in the Cpropeptide domain of the COL2A1 gene. Although PLSD-T is generally lethal, survival to adulthood has been reported in two families. 